\title{
Consequences of Customer Dissatisfaction in Upscale and Budget Hotels: Focusing on Dissatisfied Customers' Attitude Toward a Hotel
}

Bona Kim ${ }^{a}$, Seongseop (Sam) Kim ${ }^{\mathrm{b}}$, and Cindy Yoonjoung $\mathrm{Heo}^{\mathrm{c}}$

${ }^{\text {a }}$ Department of Business Administration and Tourism and Hospitality Management, Mount Saint Vincent University, Halifax, Nova Scotia, Canada;

${ }^{\mathrm{b}}$ School of Hotel and Tourism Management, The Hong Kong Polytechnic University, Kowloon, Hong Kong;

${ }^{c}$ Ecole hôtelière de Lausanne, HES-SO/University of Applied Sciences Western Switzerland, Switzerland

\begin{abstract}
It is important to understand customer dissatisfaction in order to maintain a sustainable business, given that the negative effects of customer dissatisfaction in service businesses may be even greater than the positive effects of satisfaction. This study investigates customer dissatisfaction and its consequences by focusing on the mediating role of attitude toward a hotel according to different hotel classes related to customer expectation level. The results show a mediating role for attitude in the relationship between customer dissatisfaction and specific negative behavioral intentions. This study broadens our knowledge of customer dissatisfaction and the role of attitude toward a hotel in the relevant literature. The empirical findings demonstrate that regardless of hotel type, customer dissatisfaction significantly affects their attitude and their consequent negative behavioral intention.
\end{abstract}

\section{KEYWORDS}

Attitude toward a hotel; complaining behavior; customer dissatisfaction; negative word-ofmouth; switching behavior; upscale and budget hotels

To cite this article:

Kim, B., Kim, S. S., \& Heo, C. Y. (2019). Consequences of customer dissatisfaction in upscale and budget hotels: focusing on dissatisfied customers' attitude toward a hotel. International Journal of Hospitality \& Tourism Administration, 20(1), 15-46.

DOI: $10.1080 / 15256480.2017 .1359728$ 


\section{Consequences of customer dissatisfaction in upscale and budget hotels: focusing on dissatisfied customers' attitude toward a hotel}

\section{INTRODUCTION}

The level of customer satisfaction is an indicator that is considered to be directly related to a company's positive reputation and future profits (Anderson et al., 1994; Homburg et al., 2005). Satisfied customers remain loyal for longer and are more likely to repurchase and spread positive word-of-mouth (Anderson et al., 2004; Kim, 2011; Kim et al., 2013). However, when customers are dissatisfied, the results are unfavorable. Such customers may express their unhappiness by spreading negative word-of-mouth, switching service provider, or complaining to the company (Richins, 1987; Zeelenberg \& Pieters, 2004; Zeithaml et al., 1996).

Interestingly, research shows that the negative effects of customer dissatisfaction on service businesses may be even greater than the positive effects of customer satisfaction (Anderson, 1998). The impact of negative word-of-mouth is 2-10 times stronger than that of positive reports (Schlossberg, 1991; TARP, 1981). Other studies have found that $75 \%$ of dissatisfied customers make negative comments to their acquaintances, whereas only $38 \%$ of satisfied customers share their positive experience of a service (Hoffman \& Chung, 1999).

Furthermore, giving customers an unpleasant experience also increases the number of complaints about a company's products or services. Customer complaints can therefore be considered as a form of critical feedback which may enable a service provider to rectify its problems and shortcomings (Jones et al., 2002; Lewis, 1983; Sanes, 1993). As a result, complaining behavior is regarded as a powerful reaction that requires a response from a provider, necessitating additional cost and effort (Ro \& Wong, 2012). 
The importance of minimizing customer dissatisfaction is also a priority for companies because bringing in a new customer requires more effort than retaining an existing one (Reichheld, 1996; Reichheld \& Sasser, 1990). For example, Reichheld (1996) reports that the cost of bringing in a new customer is five times higher than that of retaining an existing one. In other words, failing to satisfy customers can increase a company's costs by causing them to switch to another service provider. Retaining customers is a significant issue in yield management. Reichheld and Sasser (1990) find that a reduction of 5\% in service defection can generate a profit of up to $85 \%$. As a result, customer dissatisfaction has been gradually recognized as an important aspect of business and one that has a negative impact on purchase behavior and overall profitability (Zeelenberg \& Pieters, 2004).

There is a general belief that satisfaction and dissatisfaction are opposed concepts, with dissatisfaction being the consumer's response to an evaluation when one feels less satisfied. Customer satisfaction is most commonly measured using a bipolar continuum ranging from highly dissatisfied to highly satisfied (Yi, 1990). However, according to Herzberg's two-factor theory, satisfaction and dissatisfaction are not in fact on a continuum where one increases as the other diminishes. Herzberg and colleagues (1966, 1993) propose that the causes of customer dissatisfaction may be different from those of customer satisfaction, identifying this as a bidimensional concept.

Some scholars separate out positive and negative measurements for satisfaction and dissatisfaction, respectively (Babin \& Griffin, 1998). It can be argued that customer satisfaction and dissatisfaction are uni- or bi-dimensional concepts (Maddox, 1981; Swan \& Combs, 1976). Even though most studies tend to regard them as uni-dimensional, in the sense that both can be generated using the same factors, a handful of studies argue for a bi-dimensional 
conceptualization (Yi, 1990). However, others suggest that the uni-dimensional framework may not be sufficient to generate both satisfaction and dissatisfaction; while the presence of specific factors generates the former, their absence does not necessarily lead to the latter (Alegre \& Garau, 2010).

Based on this theoretical framework, this study explores the significance of customer dissatisfaction as an independent concept, to be differentiated from satisfaction, by analyzing customers' reactions to unsatisfactory outcomes and their resulting behaviors. People tend to have particular ways of judging how they view the world, what they think, and what they do. One of the criteria for making cognitive judgments about an individual tendency is attitude (Lutz, 1991; Maio \& Haddock, 2010; Olson \& Mitchell, 1975; Wicker, 1969). With customer dissatisfaction receiving more attention, it is crucial to understand its impact on individual judgment and how this influences behavior.

Attitude can explain the predictive utility through which individuals formulate the intention to engage in a certain behavior (Ajzen, 1985, 1991). A few studies examine the importance of attitude in predicting customers' behavior in the hospitality context, and only some in particular focus on negative behavioral intentions (Cheng \& Lam, 2008; Cheng et al., 2005 , 2006). However, these studies use attitude mainly in terms of taking attitude toward a given negative behavior to describe a belief about it, such as an attitude toward complaining or spreading negative word-of-mouth (Cheng \& Lam, 2008; Cheng et al., 2005. 2006; Kim \& Chen, 2010; Kim et al., 2003; Yuksel et al., 2006). Limited work so far has investigated overall attitude toward a hotel in the context of customer dissatisfaction.

In addition, another phenomenon that is generally referred to be a necessary strategy considering hotel products, facilities, and services, is particular types of hotels (Kim et al., 2013). 
Different classes of hotels provide different hotel facilities and services, and the hotel management aims to provide a preferable level of performance by fulfilling the level of customers' expectation (Costa et al., 2004). Since expectation level acts as a guideline for evaluation (Cardozo, 1965; Olson \& Dover, 1979), each individual accordingly expects a certain level of tangible facilities and intangible services when customers stay at a particular hotel.

High expectations are related to the probability of feeling less satisfied, and vice versa. This seminal study later formed the basis of the expectancy-disconfirmation theory as set out by Oliver (1980). However, previous studies only demonstrated that customer satisfaction is more likely to be directly relevant to expectations, but did not test dissatisfaction separately. Therefore, hotel class is one of criteria that is related to creating customers' expectation level (Knutson et al., 1993). As a result, the level of customer expectation for a hotel can vary according to hotel class, and it may be one of the significant factors in assessing satisfaction and dissatisfaction (Dolnicar, 2002). Therefore, hotel class related to customers' expectation level as an important guideline for evaluation should be considered.

Despite this, our understanding of customer dissatisfaction and its effect on attitude toward a hotel and the resulting negative behavioral intentions, in terms of identifying the consequences of customer dissatisfaction in the context of hotel management, remains limited. In particular, little research to date has examined the subsequent attitude toward a hotel after an episode of dissatisfaction, and the negative aspects of their corresponding behavioral intention. Moreover, the consequence of customer dissatisfaction focusing on attitude by class of hotel has not been extensively discussed in the hotel management literature.

As a result, this study has two main objectives. First, it examines the mediating effect of attitude toward a hotel between customer dissatisfaction and negative behavioral intentions, 
namely switching service provider, spreading negative word-of-mouth, and complaining.

Second, it is designed to investigate the consequences of customer dissatisfaction in upscale and budget hotels, respectively. To facilitate these objectives, this study attempts to explore the strength and sign of the path coefficients identified by using structural equation modeling (SEM) on samples drawn from upscale and budget hotels.

\section{LITERATURE REVIEW}

\section{Customer dissatisfaction and its consequences}

Customer dissatisfaction is defined as a customer's affective status when he or she experiences discomfort caused by service failure (Fornell \& Wernerfelt, 1987; Jiang et al., 2010). Compared to the amount of academic attention paid to customer satisfaction, the importance of dissatisfaction has been less strongly highlighted in consumer behavior studies (Babin \& Griffin, 1998; Richins, 1983; Swan \& Combs, 1976). Moreover, the issue of customer dissatisfaction has been not widely researched in the hospitality context. The review which follows classifies studies in this area into three categories.

The first category deals with customers' emotional response to dissatisfaction (Jang et al., 2013; Mattila \& Ro, 2008; Sánchez-García \& Currás-Pérez, 2011; Velázquez et al., 2009). Mattila and Ro (2008) suggest that negative emotions triggering service failure can be classified as anger, disappointment, regret, and worry. They show that these emotions affect behavioral intention such as complaining, spreading negative word-of-mouth, or switching provider. This study also shows that anger, disappointment, and regret have a substantial effect on behavioral intention, while worry does not. Similarly, Sánchez-García and Currás-Pérez (2011) confirm the mediating effect of anger and regret on the relationship between customer dissatisfaction and 
behavioral intention in hotels and restaurants. In particular, they show that the anger of hotel customers affects their intention to switch provider, spread negative word-of-mouth, and complain, whereas their regret affects only the first two of these.

Velázquez et al. (2009) examine the cognitive and affective antecedents of customer dissatisfaction in a restaurant setting. They show that cognitive factors, such as causality attributions and inequity, and the affective factors such as negative affect have significant and positive effects on customer dissatisfaction. In particular, they point out that the cognitive factors had more impact on dissatisfaction than the affective. Jang et al. (2013) analyze the effect of negative emotions on dissatisfaction and behavioral intention. They show that regret and disappointment are critical in determining customer dissatisfaction, leading to negative word-ofmouth and switching.

The second category of research sets out to identify the role of personal values in expressing customer dissatisfaction (Chan \& Wan, 2009; Chan et al., 2007). Chan and Wan (2009) analyze Chinese customers' individual values about face and fate, showing that these factors have a moderating effect on dissatisfaction (Chan \& Wan, 2009). In similar vein, Chan et al. (2007) propose the importance of a personal value orientation that indicates face consciousness and fate submissiveness. They show that these personal values affect customer dissatisfaction in terms of the process and outcome of service failure in both hotels and restaurants.

The third category of studies explore whether the strength of the relationship between customer and service provider affects the dissatisfaction response (Ha \& Jang, 2009; Yang \& Mattila, 2012). Yang and Mattila (2012) emphasize the effect of relationship strength and type of service failure on consumers' complaining behavior and spreading of negative word-of-mouth. 
They show that most dissatisfied customers do not complain, but instead express negative wordor-mouth or end their business relationship with the firm. In addition, customers who have a strong relationship with the service provider do not complain since the service failure is offset by that relationship. Ha and Jang (2009) examine the effect of recovery efforts on perceived justice and behavioral intention according to the level of relationship quality in a service recovery strategy context. They show that high recovery efforts very positively affect customers' perceptions of justice, which lead to positive word-of-mouth and revisit intention for both good and poor relationships.

These studies focus on customer dissatisfaction as a negative affective status and investigate it in the context of negative post-purchase actions. However, the limitations of these studies include a lack of any attempt to conceptualize a model which includes dissatisfaction and negative post-purchase behavior, and the failure to identify any mediating variables between customer dissatisfaction and negative behavioral intention. It is accordingly necessary to analyze the consequences of customer dissatisfaction by exploring customers' overall evaluation of service failures. Therefore, this study examines the attitudinal responses of customers that are likely to lead to behavioral changes.

\section{Attitude toward a hotel as a salient determinant of customers' evaluation}

Attitude is an element of judgment in evaluating an individual tendency (Lutz, 1991; Olson \& Mitchell, 1975; Wicker, 1969). In an early study on attitude, Allport (1935) declares that it is the most distinctive and indispensable concept in social psychology. It has generally been seen as a precursor of behavior and a salient determinant of how a person behaves in daily life, since it has a pivotal role in affecting individual behavioral tendencies (Allport, 1935, 
Cohen, 1964; Lutz, 1991). Attitude typically implies how much people like or dislike an object, and is commonly defined as a summary evaluation of objects with paired anchors of bipolar measurement (Eagly \& Chaiken, 1993; Fazio, 1995; Fishbein \& Ajzen, 1975; Zanna \& Rempel, 1988).

Attitude has been widely researched in the context of its impact on behavior (Fazio et al., 1989; Fishbein \& Ajzen, 1975; Lutz, 1991; Olson \& Mitchell, 1975; Priester et al., 2004). In particular, the formation of attitude has been examined by a cognitive model of human behavior. Attitude is an independent predictor of behavioral intention (Ajzen, 1985, 1991), which is defined as "the degree to which a person has a favorable or unfavorable evaluation or appraisal of the behavioral in question" (Ajzen, 1991, p. 188). It plays the role of a salient behavioral belief representing the individual's assessment of the significance of the consequences (Han et al., 2010).

In terms of the process of attitude acquisition, the steps of formation and change have been distinguished (Ekinci et al., 2008; Oliver, 1980; Olson \& Mitchell, 1975; Vermeulen \& Seegers, 2009). They indicate that the development of positive attitudes produces a favorable change in behavior (Allport, 1935; Fazio et al., 1989). Thus, the formation of a favorable attitude is regarded as an essential way to understand customers' behavioral processes when purchasing a product or service (Kokkinaki \& Lunt, 1999; Priester et al., 2004). In particular, it conceptualized a satisfaction model elucidated by two types of attitude, namely antecedent and consequent (Ekinci et al., 2008; Oliver, 1980). In the hotel context, an antecedent attitude can be defined as a customer's overall feeling about a hotel. This refers to a general image of it that may have been formed by the effect of several precursor factors such as marketing communications, previous experiences, or word-of-mouth (Ekinci et al., 2008; Vermeulen \& Seegers, 2009). On 
the other hand, a consequent attitude refers to the feeling created after a customer's evaluation, and is used to measure the consequences of that evaluation. In addition, the interaction of attitude toward both an object and a situation is a better predictor of behavior than the attitude toward either alone (Rokeach \& Kliejunas, 1972).

Different approaches to hotel-related attitudes have been analyzed in the hospitality literature (Bowen \& Chen, 2001; Lee et al., 2008; Vermeulen \& Seegers, 2009). Vermeulen and Seegers (2009) point out that exposure to positive information about a hotel effects a positive change of attitude toward it, whereas exposure to negative information influences a negative attitude change. In similar vein, Lee et al. (2008) show that receiving a high proportion of negative information about a hotel has a significant impact on developing a negative attitude toward it. In addition, Bowen and Chen (2001) suggest that attitude toward a hotel can be measured using the concept of loyalty because the attitudinal measurement refers to emotional and psychological attachment.

In the expectancy-disconfirmation model of Oliver (1980), his focus has shifted to the relationships among expectations, disconfirmation, attitude, satisfaction, and behavioral intention. The finding shows that the influence of expectations and their disconfirmation in performance leads to positive attitude and results in customer satisfaction. However, although negative disconfirmation results in dissatisfaction according to the theory, it did not empirically prove the relationship between customer dissatisfaction and attitude, and that between the attitude and negative behavioral intention. By following up the work of Oliver (1980), Ekinci et al. (2008) show that customer satisfaction is a significant indicator of customers' attitude toward a service firm, while overall attitude influences intention to return. Here, notable focus on the 
expectancy-disconfirmation theory has leant toward understanding of both satisfaction and dissatisfaction on a continuous level (Johns \& Howard, 1998).

Most studies on attitude in the context of customer dissatisfaction show that attitude toward complaining positively correlates with complaint intention (Kim \& Chen, 2010; Kim et al., 2003; Yuksel et al., 2006). A personal attitude mainly indicates an attitude toward a certain action (Cheng \& Lam, 2008; Cheng et al., 2005, 2006; Han et al., 2010; Kim \& Chen, 2010; Kim et al., 2003; Yuksel et al., 2006). Though attitude can describe an individual's overall evaluation of an act and may serve to predict behavioral beliefs, there has not yet been an investigation of overall attitude toward a hotel in the context of customer dissatisfaction.

In summary, if customers evaluate a product or service negatively (i.e. they are dissatisfied), they are more likely to form a negative attitude to it and less likely to purchase or consume it (Ekinci et al., 2008; Oliver, 1980; Priester et al., 2004; Vermeulen \& Seegers, 2009). However, previous studies have not assessed the role of attitude toward a hotel in the context of customer dissatisfaction. Herzberg's two-factor theory as the ground theory of this study states that satisfaction and dissatisfaction are not at opposite ends of the same continuum. In other words, the opposite of satisfaction is not dissatisfaction, but the absence of satisfaction, and the converse is also true (Herzberg et al., 1958; Maddox, 1981). Thus, this study empirically examines the effect of customer dissatisfaction on attitude toward a hotel and subsequent negative behavioral intention. This is because it is important to understand the mediating role of customer attitude toward a hotel in causing the key consequences of customer dissatisfaction.

\section{Hotel class related to customer expectation}


Hotels can be classified into different levels according to various assessment criteria such as price, service strategy, or target customers (Garcia-Falcon \& Medina-Muñoz, 1999). Hotel class differs according to particular property features and the level of service and facilities provided (Jeong \& Jeon, 2008; Musante et al., 2009). One of the universal hotel rating systems is the star-rating system. In this, hotels are evaluated using standards such as quality of physical facilities, level of service, atmosphere, and rates (Ingram \& Roberts, 2000; Jeong \& Jeon, 2008). The rating strongly influences customer satisfaction with the service because people believe that a hotel with a higher star rating will provide a higher level of hospitality service (Ariffin \& Maghzi, 2012).

Some studies have noted a theoretical aspect of different customer expectation relevant to different hotel class (Griffin et al., 1997; Knutson, 1988; Knutson et al., 1993). A strand of these studies has demonstrated that customers who stay at a higher level of hotel class have a higher level of expectation for service and room amenities and they are more willing to pay than those who stay at a lower level of hotel class (Dolnicar, 2002; Griffin et al., 1997; Knutson, 1988; Knutson et al., 1993). Knutson and colleagues $(1988,1993)$ found that customers' expectations of hotel services and room amenities are linked to hotel classes. Knutson (1988) showed that guests of luxury hotels have a higher level of expectation, while the reverse is true in economy properties when they consider hotel services, room amenities, and service quality, such as location, reputation, and value for money.

The level of customer dissatisfaction is affected by customer expectation because the latter determines how a person evaluates whether or not an experience is satisfactory (Zainol et al., 2010). The difference between upscale and budget hotels may indicate they belong to a 
different hotel class. There is a need to explore dissatisfaction and its consequences between customer groups in different classes of hotel.

\section{Conceptualization and hypotheses development}

Research in the hospitality field has examined a wide range of behavioral responses to, and intentions consequent upon, service failure (Bolfing, 1989; Jang et al., 2013; Mattila \& Ro, 2008; Sánchez-García \& Currás-Pérez, 2011; Zeelenberg \& Pieters, 2004). Mattila and Ro (2008) examined the relationships between negative emotions and dissatisfaction responses and showed that the emotions associated with dissatisfaction may lead to complaining, spreading of negative word-of-mouth, and switching service provider. Sánchez-García and Currás-Pérez (2011) also showed that anger - as a negative emotion resulting from an unsatisfactory customer experience had a significant effect on switching service provider, spreading negative word-of-mouth, and complaining behaviors. Zeelenberg and Pieters (2004) identified positive relationships among negative emotions, customer dissatisfaction, and certain negative behavioral reactions. Jang et al. (2013) found that customer dissatisfaction triggered by regret and disappointment influenced switching service provider and spreading negative word-of-mouth.

In light of this body of research, it is plausible to suggest that customer dissatisfaction has an impact on post-purchase behavioral intentions. In particular, it may be assumed that there are positive relationships between customer dissatisfaction and the three main negative behavioral intentions (switching service provider, spreading negative word-of-mouth, and complaining). In light of the literature review, we posit the following hypotheses.

Hypothesis 1. Customer dissatisfaction is positively related to switching service provider.

Hypothesis 2. Customer dissatisfaction is positively related to spreading negative word-of-mouth. 
Hypothesis 3. Customer dissatisfaction is positively related to complaining.

A number of studies have attempted to assess the relationship between the level of customer satisfaction and its consequences (Anderson, 1998; Anderson \& Sullivan, 1993; Bowen \& Chen, 2001; Ekinci et al., 2006; Oliver, 1980; Olsen, 2002). Vermeulen and Seegers (2009) showed that negative information generates a negative attitude toward a hotel. Lee et al. (2008) also found that negative information has a significant impact on negative attitude toward a hotel. Attitude is defined as an enduring feeling of evaluation toward a particular object, such as a favorable or unfavorable response. It has long been considered a useful predictor of customer behavior toward a product or service (Priester et al., 2004; Lutz, 1991; Olson \& Mitchell, 1975). The formation of an attitude has been found to be an essential way to understand customers' purchase decisions (Kokkinaki \& Lunt, 1999; Priester et al., 2004).

There is a consensus that overall attitude positively affects post-purchase behaviors as an outcome (Cheng et al., 2005, 2006; Ekinci et al., 2006; Howard, 1974; Oliver, 1980). For example, Howard (1974) found that the post-purchase attitude of satisfied customers affects future purchase intention. Oliver (1980) showed that customer attitude is positively associated with future intention in his satisfaction model. Likewise, Ekinci et al. (2006) examined the effect of customers' overall attitude on intention to return. In a similar vein, the development of a negative attitude unfavorably affects behavioral change (Lee et al., 2008; Vermeulen \& Seegers, 2009). Based on these studies, therefore, this study explores the effect of attitude toward a hotel on negative behavioral intention in an unsatisfactory situation.

Although previous studies have investigated patterns of relationship in which satisfaction correlates with its positive consequences, there has been little examination of the mechanism 
underlying the relationship between customer dissatisfaction and its negative outcomes. Furthermore, a customer's attitude toward a hotel may play a mediating role; however, the particular role of attitude toward a hotel as it affects the consequences of dissatisfaction has been overlooked. In light of the cognitive theory proposed by Oliver (1980) - which concerns customer satisfaction and its consequences - and of the extended model of customer satisfaction developed by Ekinci et al. (2006), we assume the relation between customer dissatisfaction and negative behavioral intentions to be mediated by a customer's attitude toward a hotel. Accordingly, we posit the following hypotheses.

Hypothesis 4. Attitude toward a hotel mediates the effect of customer dissatisfaction on switching service provider.

Hypothesis 5. Attitude toward a hotel mediates the effect of customer dissatisfaction on spreading negative word-of-mouth.

Hypothesis 6. Attitude toward a hotel mediates the effect of customer dissatisfaction on complaining behavior.

\section{METHODOLOGY}

\section{Measurement}

This study has reviewed five constructs (customer dissatisfaction, attitude toward a hotel, switching service provider, spreading negative word-of-mouth, and complaining intention) in the literature and attempted to modify them for use in the hotel context. Firstly, three items in the dissatisfaction-based scale were used to measure the customer dissatisfaction construct (Chan \& Wan, 2009; Chan et al., 2007; Zeelenberg \& Pieters, 2004). All three items were measured using a 7-point Likert-type scale ranging from $1=$ not totally dissatisfied to $7=$ highly dissatisfied. 
Secondly, seven items were employed to measure attitude toward a hotel (Ekinci et al., 2006; Maio \& Olson, 1994). Attitude is typically operationalized using bipolar scales (Cacioppo \& Petty, 1981). In particular, Ajzen and Fishbein (1980) suggest the semantic differential scale to measure attitude. Since attitude toward a hotel is defined in this study as a judgment of overall feelings about a hotel after experiencing an unsatisfying situation, the construct was developed through a bipolar evaluative dimension using seven semantic differential scales.

Customers' negative behavioral intention stemming from dissatisfaction indicates the range of potential dissatisfaction responses for that individual (Bolfing, 1989; Chan \& Wan, 2009). On the basis of the literature review, behavioral intention was operationalized as three constructs; switching service provider, spreading negative word-of-mouth, and complaining (Bougie et al., 2003; Mattila \& Ro, 2008; Sánchez-García \& Currás-Pérez, 2011; Zeelenberg \& Pieters, 2004). Each construct was measured using four items and a total of 12 items with responses were collected using a 7-point Likert-type scale ranging from " $1 "=$ "strongly disagree" to "7" = "strongly agree".

To guarantee content validity, a pre-test was conducted by 10 academics in the hospitality and tourism field in order to examine the wording and proper meaning of the items, and check for any grammatical errors. After amending items in the questionnaire accordingly, a pilot was conducted from October $1^{\text {st }}$ to $5^{\text {th }}, 2014$. The pilot test employed a panel from an online survey company based in the US which provides a particular web-based survey platform. The company assists with academic and industrial research for over 6,000 business clients across all industries in 75 countries and 1,300 universities worldwide (see www.qualtrics.com). In the data collection for the pilot, two screening questions were included for respondents to report whether they had had an unsatisfactory experience after using a hotel and the type of hotel in which they generally 
stayed. A total of 250 completed questionnaires were collected. Among them, 124 (74 users of upscale and 50 users of budget hotels) were used in the analysis, with the remaining 126 excluded due to multiple missing values. On the basis of reviewers' comments about the logical flow of the survey process, a further slight modification to the instrument was made. Based on this rigorous process, the questionnaire was finalized for use in the main survey.

This study is an empirical investigation of customer dissatisfaction associated with attitude toward a hotel and negative behavioral intention. US domestic travelers were randomly selected as the study population by an online survey company and a sampling unit was an individual traveler who had had an unsatisfactory experience when he/she stayed at least once in either an upscale or a budget hotel within the previous 12 months before the survey was conducted in 2014. Through the screening questions, only those who indicated having a dissatisfied hotel stay experience were asked to participate in the survey. Respondents were also designated according to the hotel types in which they generally stayed; either upscale (four or five stars) or budget (one or two stars). The main survey ran from October 10 to November 25, 2014. A total of 1,465 respondents were sampled with 647 valid questionnaires ( 325 from upscale and 322 from budget hotel users) retained for the analysis after excluding those with multiple missing values. The final response rate was $44.16 \%$.

\section{RESULTS}

\section{Profile of respondents}

Nearly $60 \%$ of the respondents in the upscale hotel dataset are female. About $48 \%$ are aged $21-40$, and about $35 \%$ are older than 51 . Around $60 \%$ of the respondents are married and about $60 \%$ are educated to Bachelor's degree level or above. In terms of occupation, the 
categories are professional/executive $(21.8 \%)$, retired $(13.8 \%)$, homemakers $(13.5 \%)$, in education (10.8\%), and company worker (10.2\%). The majority has an annual household income of more than US\$ 60,000 (63.7\%). The main national and ethnic groups represented are American (95.7\%) and Caucasian (79.1\%), respectively. In terms of hotel stay patterns, the main reason reported for staying in a hotel is leisure-related purposes $(78.8 \%)$. Concerning their experiences of staying in hotels in the year 2013 , about $84 \%$ of respondents had taken more than two trips that year. Approximately 50\% of them spent more than US\$ 151 per night on their hotel stay.

In the budget hotel dataset, nearly $67 \%$ of respondents are female. Their age is almost equally distributed with around $20 \%$ in each of the categories except for 20 or less $(2.5 \%)$ and $41-50(13.8 \%)$. Approximately $52 \%$ of them are married. Interestingly, about $52 \%$ of the respondents are college students or have been educated to high school level or lower. In addition,

nearly $45 \%$ hold a Bachelor's degree. These respondents are accordingly less well-educated than those in the upscale hotel subgroup. In terms of occupation, about $20 \%$ are retired, followed by homemakers (11.5\%), professional/executive (10.2\%), and company worker $(9.9 \%)$. Nearly $62 \%$ of them have an annual household income below US\$ 60,000. Most are American (96.3\%) and Caucasian $(80.4 \%)$. Their main reason for staying in a hotel is leisure $(68.3 \%)$. About $81 \%$ of these respondents have stayed in a hotel more than twice. Interestingly, nearly $88 \%$ of them spent between US\$ 51 and US\$150 on their rooms.

\section{Results of confirmatory factor analysis}

Before conducting the SEM analysis, a CFA is carried out to examine how well the measured variables reflected the corresponding constructs of the proposed measurement theory, 
in order to confirm construct validity; that is, the accuracy of measurement (Kline, 1998). A CFA analysis of the five constructs in the upscale hotel dataset generates an acceptable level of model fit with the exception of the chi-square value $\left(\chi^{2}=596.31, d f=199, \chi^{2} / d f=2.86, p<.000\right)$. However, since the chi-square value is sensitive to sample size, other fit indices are also considered when evaluating a model (Bollen, 1989; Hair et al., 2009; Jöreskog \& Sörbom, 1993). The upscale hotel group dataset shows a good model fit in terms of the Turker-Lewis Index $(\mathrm{TLI})=.96$, Comparative Fit Index $(\mathrm{CFI})=.96$, Root Mean Square Error of Approximation $($ RMSEA $)=.08$, and Normed Fit Index $(\mathrm{NFI})=.95$. Construct reliability is also evaluated by confirming the composite construct reliability (CCR), which is regarded as acceptable when the value is greater than .70 (Fornell \& Larcker, 1981; Hair et al., 2009). In this study, construct validity is excellent since the CCR values of all five constructs in the upscale hotel dataset are greater than .80 .

Validity is assessed by means of a high level of both convergent and discriminant validity (Hair et al., 2009). Convergent validity requires that items as indicators of a specific construct should share a high proposition of the variance in common. To assess this, the magnitude of $t$ value between constructs is estimated and the average variance extracted (AVE) is calculated. Since the items on the five constructs of the upscale hotels dataset show significant $t$-values at the .001 level, the measurement items are considered to have high convergent validity. In addition, all the values of AVE are assessed to clarify how much the latent variable explains the variance of the indicators (Fornell \& Larcker, 1981). Since all AVE values are above .50, the constructs are satisfactory in terms of convergent validity (Hair et al., 2009).

The five constructs in the budget hotel dataset indicate an acceptable level of model fit, again with the exception of the chi-square value $\left(\chi^{2}=592.05, d f=199, \chi^{2} / d f=2.98, p<.000\right.$, 
$\mathrm{TLI}=.95, \mathrm{CFI}=.96, \mathrm{RMSEA}=.08$, and $\mathrm{NFI}=.93)$. All items on the five constructs in the budget hotel dataset show significant $t$-values at the .001 level. All AVE values are above or close to .50 , indicating a satisfactory level. The CCR results indicate that the values of all five constructs are greater than .70. It can therefore be seen that all the measurement items for each construct show acceptable construct and convergent validity. The results are shown in full in Table 1.

\section{Table 1}

Discriminant validity refers to the extent to which a given construct differs from other constructs (Hair et al., 2009). The squared multiple correlation measures the reliability of measurement items by presenting the proportion of the variance for each what is accounted for by each construct. A satisfactory level of discriminant validity is achieved when the estimated AVE for each construct is greater than the squared multiple correlation for the corresponding constructs (Fornell \& Larcker, 1981). All AVE values shown in Table 2 are close to or greater than the highest squared correlations for both datasets. Therefore, the measurement model also demonstrates discriminant validity (Fornell \& Larcker, 1981).

\section{Table 2}

\section{Results of the structural equation modeling}

After establishing the adequacy of the measurement model - in terms of its overall fit, reliability, and validity - SEM analysis was conducted to test the main conceptual model and the six hypotheses. SEM is one of the preferred methods for determining how well a proposed model 
fits the observed data by revealing path relationships (Hayes, 2009). In addition, SEM can show the linkages between independent variables and dependent variables through one or more intervening pathways by providing estimates of indirect effects (Preacher \& Hayes, 2004; Ro, 2012). A maximum likelihood estimation method was used to estimate the proposed model and to check whether it was consistent with the data collected in this study. The goodness-of-fit indices used to assess the structural model fit and the estimated standard path coefficients, $t$ values, and statistical significance of the structural coefficients are shown in Figure 1.

\section{Figure 1}

The results of the SEM analysis show that the hypothesized model fits the data adequately $\left(\chi^{2}=959.91, d f=202, \chi^{2} / d f=4.75, p<.000, \mathrm{TLI}=.92, \mathrm{CFI}=.93, \mathrm{RMSEA}=.11, \mathrm{NFI}=.91\right)$. In particular, the RMSEA values are close to the cut-off criterion: RMSEA values of .08 to .10 can be taken as indicating an acceptable fit (MacCallum et al., 1996). This study follows Baron and Kenny's (1986) approach of causal steps to examine the first assumption of mediation. As Table 2 shows, the correlation coefficients yielded by the upscale hotel dataset indicate that dissatisfaction is positively and significantly related to switching service provider $(\mathrm{r}=.23, p<.01)$, spreading negative word-of-mouth $(\mathrm{r}=.23, p<.01)$, and complaining $(\mathrm{r}=.19, p<.01)$; similar results were yielded by the budget hotel dataset (for switching service provider, $\mathrm{r}=.26, p<.01$; for negative word-of-mouth, $\mathrm{r}=.25, p<.01$; and for complaining, $\mathrm{r}=.19, p<.01$ ), with acceptable model fit $\left(\chi^{2}=711.11, d f=202, \chi^{2} / d f=3.52, \mathrm{p}<.001, \mathrm{TLI}=.93, \mathrm{CFI}=.94, \mathrm{RMSEA}=.09, \mathrm{NFI}=.92\right)$.

Figure 2 illustrates the direct effects of customer dissatisfaction on switching service provider, spreading negative word-of-mouth, and complaining behavior (for both the upscalehotel and budget hotel datasets). Supporting the hypotheses, the results of the analysis of the 
upscale hotel dataset indicate that there are direct effects of customer dissatisfaction on switching service provider $(\mathrm{r}=.236, p<.001)$, negative word-of-mouth $(\mathrm{r}=.236, p<.001)$, and complaining $(\mathrm{r}=.216, p<.001)$. The results of the analysis of the budget hotel dataset indicate that there are direct effects of customer dissatisfaction on switching service provider $(\mathrm{r}=.263, p<.001)$, negative word-of-mouth $(\mathrm{r}=.271, p<.001)$, and complaining $(\mathrm{r}=.227, p<.001)$. Thus, Hypotheses 1,2 , and 3 are supported.

\section{Figure 2}

In order to test Hypotheses 4, 5, and 6, firstly the correlation coefficients were calculated. As Table 2 shows, the correlation coefficients of the relevant variables in the upscale hotel dataset indicate that customer dissatisfaction is positively related to attitude toward a hotel $(\mathrm{r}=.39, p<.01)$; and attitude toward a hotel is positively related to negative behavioral intentions (for switching, $\mathrm{r}=.55, p<.01$; for negative word-of-mouth, $\mathrm{r}=.49, p<.01$; and for complaining, $\mathrm{r}=.42, p<.01)$. With regard to the budget hotel dataset, the correlation coefficients indicate that customer dissatisfaction is positively related to attitude toward a hotel $(\mathrm{r}=.28, p<.01)$ and attitude toward a hotel is positively related to negative behavioral intentions (for switching, $\mathrm{r}=.72, p<.01$; for negative word-of-mouth, $\mathrm{r}=.60, p<.01$; and for complaining, $\mathrm{r}=.51, p<.01$ ). In addition, the four estimated path coefficients indicating the direct effects of the four constructs are statistically significant at the .001 level.

As Figure 1 illustrates, the most significant relationship is the direct effect of customer dissatisfaction on attitude toward a hotel $(\mathrm{r}=.41, p<.001)$. This means that customers who are highly dissatisfied with an upscale hotel are likely to form a negative attitude toward it. The other three direct effects of attitude toward a hotel are the effects on switching service provider 
$(\mathrm{r}=.56, p<.001)$, negative word-of-mouth $(\mathrm{r}=.50, p<.001)$, and complaining $(\mathrm{r}=.50, p<.001)$. The results indicate that customers who have a more negative attitude toward a hotel are more likely to intend to switch service provider, spread negative word-of-mouth, and to complain. With regard to the analysis of the budget hotel dataset, the four path coefficients are statistically significant at the 0.001 level. The most significant relationship is the direct effect of customer dissatisfaction on attitude toward a hotel $(\mathrm{r}=.28, p<.001)$, followed by the direct effect of attitude toward a hotel on switching service provider $(\mathrm{r}=.71, p<.001)$, negative word-of-mouth $(\mathrm{r}=.63$, $p<.001)$, and complaining $(\mathrm{r}=.55, p<.001)$.

In order to determine whether the indirect mediation effects were significant, the confidence intervals for the lower and upper bounds were calculated. Percentile and biascorrected percentile bootstrap tests were performed to calculate $90 \%$ confidence intervals with 2,000 samples (Hayes, 2009; Preacher \& Hayes, 2008). As Table 3 shows, the outcomes of the bootstrap test for the upscale hotel dataset indicate that attitude toward a hotel mediates the relationship between customer dissatisfaction and switching service provider $(\mathrm{r}=.23, p<.01)$, between customer dissatisfaction and negative word-of-mouth $(\mathrm{r}=.20, p<.01)$, and between customer dissatisfaction and complaining $(\mathrm{r}=.20, p<.01)$. With regard to the budget hotel dataset, attitude toward a hotel mediates the relationship between customer dissatisfaction and switching service provider $(\mathrm{r}=.12, p<.01)$, between customer dissatisfaction and negative word-of-mouth $(\mathrm{r}=.18, p<.01)$, and between customer dissatisfaction and complaining $(\mathrm{r}=.15, p<.01)$. There is a significant indirect effect with $90 \%$ confidence when the z-value does not lie between the lower and upper bounds (Hayes, 2009). Thus, Hypotheses 4, 5, and 6 are supported.

\section{Table 3}


To compare the structural models across the two groups of customers (i.e., those of the upscale and those of the budget hotels), as an initial step a measurement invariance test (a chisquare difference test) was conducted in order to assess measurement equivalence (Han et al., 2010; Yoo, 2002). This invariance test demonstrated acceptable model fit $\left(\chi^{2}=1188.36, d f=398\right.$, $\left.\chi^{2} / d f=2.99, p<.000, \mathrm{TLI}=.95, \mathrm{CFI}=.96, \mathrm{RMSEA}=.06, \mathrm{NFI}=.94\right)$.

Subsequently, a non-constrained model was compared to a constrained model in which the factor loading of each path was invariant. If differences in the chi-square estimates between non-constrained model and constrained model had not been significant, the two measurement models would have been shown to be invariant and this would have meant that the relationship paths could have been compared in further analysis (Yoo, 2002). The chi-square estimate of the non-constrained model and that of the constrained model with factor loadings were, respectively, $1188.36(d f=398)$ and $1217.68(d f=415)$; and the chi-square test revealed significant differences.

According to statistical result of chi-square test, $\Delta \chi^{2}=29.32$ should be not significant by being lower than $\chi_{.05}^{2}(17)=27.59, \mathrm{p}<.05$ in order to pursue multi group comparison of coefficients and loadings. However, $\Delta \chi^{2}=29.32$ is greater than the $\chi_{.05}^{2}(17)=27.59, p<.05$, that is, the chi-square test revealed significant differences. Thus the further analysis is statistically invalid. Since a minimal requirement for further comparison and analysis was not fulfilled, further multi-group analysis was not warranted in this study. For the further analyses, invariance tests for the constrained covariance model and the constrained covariance model were estimated in accordance with the five models of measurement-equivalence assessment suggested by Myers et al. (2000). However, the analyses showed that the measurement equivalence criteria were also not met. Table 4 presents the results of the measurement-invariance test of the relevant data on the groups of upscale and budget hotel customers. Therefore the combined overall dataset was 
further analyzed to demonstrate the estimates of overall model of customer dissatisfaction (see Figure 1). Figure 1 presents that four direct effects and the mediating effect of attitude toward a hotel between customer dissatisfaction and negative behavioral intention were verified in the overall model. Although the results of chi-square test and invariance tests did not support the assumption for comparing groups, we believed that the group comparison and interpretation are still meaningful. Thus, we report the separate results of two models to provide additional information for readers.

\section{Table 4}

\section{DISCUSSION AND CONCLUSIONS}

We developed and, in a hotel context, empirically tested a model derived from the satisfaction-attitude-behavior model (Oliver, 1980) - namely, a dissatisfaction-attitude-negative behavioral intention model. Most previous studies have investigated the relationship between level of customer satisfaction and post-purchase intentions (Anderson \& Sullivan, 1993; Cardozo, 1965; Oliver, 1980; Yi, 1990) and their findings agree: customer satisfaction is positively related to intention to return, loyalty, and positive word-of-mouth which are all indicators of repurchase intentions. This may explain why customer satisfaction - which is more likely to strengthen repurchase intentions - has been more actively investigated than customer dissatisfaction.

Recent studies in the hospitality field have examined a wide range of behavioral responses to, and intentions consequent upon, service failure (Jang et al., 2013; Mattila \& Ro, 2008; Sánchez-García \& Currás-Pérez, 2011; Swanson \& Hsu, 2009). These studies have concluded that highly dissatisfied customers demonstrate, as a direct consequence of their 
dissatisfaction, a strong tendency to switch service provider, spread negative word-of-mouth, and complain. However, a few studies have found that dissatisfied customers are not directly inclined, for that reason alone, to switch service provider, spread negative word-of-mouth, or complain (Bougie et al., 2003; Zeelenberg \& Pieters, 2004); these studies have revealed the importance of the role of negative emotions (such as anger, regret, and disappointment) in mediating the relationship between customer dissatisfaction and negative behavioral intentions. According to these studies, dissatisfaction alone provides insufficient motivation for individuals to engage in these three negative behaviors although unfavorable emotions are significant predictors of these responses.

The results of our empirical study reveal that a customer's attitude toward a hotel plays a significant mediating role. Most studies on customer satisfaction emphasize its positive effect on overall attitudes (Ekinci et al., 2008; Oliver, 1980). Similarly, previous studies have found that when customers perceive positive information of a hotel then their attitudes toward it will also tend to be positive (Lee et al., 2008; Vermeulen \& Seegers, 2009). In addition, empirical studies have investigated the effect of attitude toward a behavior such as complaining or negative wordof-mouth, as a response to dissatisfaction (Cheng \& Lam, 2008; Cheng et al., 2006; Kim \& Chen, 2010; Kim et al., 2003; Yuksel et al., 2006). However, our results demonstrate that attitude toward a service provider plays a significant mediating role in the relationship between dissatisfaction and its negative consequences. It is aligned with the fact that attitude itself is one of the factors that determine an evaluation on service provider (Ekinci et al., 2008; Oliver, 1980). Most important of all, the results show that dissatisfied customers form a negative attitude toward a hotel that has provided an unsatisfactory experience overall. 
In the event of service failure that leads to customer dissatisfaction, a negative attitude may be formed during the customer's subsequent evaluation process. In other words, the customer's overall judgment that the hotel is bad will be established, and that judgment will influence the customer's post-purchase behavioral intentions for the hotel concerned in a negative manner. That is, the critical influence on a customer's post-purchase behavioral intentions is the enduring judgment of a customer about whether a hotel that he/she has used is good or bad - this being a belief that is formed over time (Fishbein \& Ajzen, 1975; Olson \& Mitchell, 1975; Priester et al., 2004).

The focus of the present study is on the consequences of customer dissatisfaction in the context of two different classes of hotel. Class of hotel has a significant influence on customers' expectation levels (Knutson et al., 1993). It is therefore a significant factor in customer satisfaction and dissatisfaction (Dolnicar, 2002). Previous studies have shown that customers of high-class hotels have higher expectations of the services and amenities provided and that customers of lower-class hotels have lower ones, there being a direct relationship between such expectations and room rates (Knutson, 1988; Knutson et al., 1993). Customers of upscale hotels and those of budget hotels have different expectation levels and may exhibit different kinds of socioculturally influenced behaviors. Moreover, they constitute two different customer populations with very different sets of expectations. This is consistent with the argument that groups of people who exhibit specific patterns of sociocultural behavior express their values and attitudes in distinctive ways (Myers et al., 2000). In this study, the different hotel classes have very different kinds of customers - ones with very different expectations of the hotels they use or patronize. 
In addition, the significance and signs of the path coefficients in the SEM analyses demonstrate noteworthy patterns within both the upscale hotel and budget hotel datasets. Attitude toward a hotel was found to play a significant mediating role in the relationship between customer dissatisfaction and the three negative behavioral intentions as regards the consequences of customer dissatisfaction. It appears that dissatisfied customers - whether of upscale hotels or of budget hotels - tend to develop a negative attitude toward a hotel that has failed to meet their expectations and hence form the intention to engage in negative behaviors from the point of view of the hotel, regardless of the class of hotel. Once a customer is dissatisfied with a hotel as a result of service failure, he/she forms a negative attitude toward the hotel and subsequently negative post-purchase behavioral intentions from the point of view of the hotel concerned.

\section{IMPLICATIONS AND LIMITATIONS}

Based on the conclusion of the analyses, the following academic and practical implications are highlighted. Firstly, this study provides new theoretical insight into the consequences of customer dissatisfaction, with a particular focus on overall attitude toward a hotel and its link to customers' negative behavioral intentions. it empirically demonstrates the impact of overall attitude toward a hotel as a mediator of the likelihood of engaging in three different negative behavioral intentions. Having emphasized the significance of behavioral intention in a given setting where dissatisfaction has occurred, it is the principal predictor of behavior and can be regarded as a motivation to engage in certain activities; it also represents people's expectations of their own behavior. Fishbein and Ajzen (1975) operationalize intention as the likelihood of action. While people try to act according to their intention to engage in a certain behavior, one of the most influential determinants of such intention is attitude. Unlike the 
functional understanding of attitude, that merely explains attitude toward a particular negative action, this study gives a clear explanation of attitude toward a hotel as representing an individual's conceivable negative or unfavorable beliefs.

In particular, this study identified a mediating role for attitude toward a hotel in the relationship between customer dissatisfaction and negative behavioral intention. Dissatisfied customers directly engage in formulating a negative attitude toward a hotel and are consequently inclined to demonstrate negative postpurchase behavior because they may cautiously evaluate the hotel by determining whether they are favorable or unfavorable according to their personal values as own criteria. Such a negatively consolidated attitude may then spontaneously influence their future behavioral intention. Another reason for this may be that dissatisfied customers initially experience a transitory sentiment, such as anger, disappointment, or regret, and after a time lapse these emotions lead to negative behavioral intention (Bougie, et al., 2003; Jang et al., 2013; Sánchez-García \& Currás-Pérez, 2011; Zeelenberg \& Pieters, 2004). These arguments are consistent with a conventional definition of attitude as a prolonged and persistent overall feeling that ultimately leads to behavior (Priester et al., 2004; Lutz, 1991; Olson \& Mitchell, 1975).

Secondly, the findings of this study imply that service recovery for dissatisfied customers is highly significant given that attitude toward a hotel acts as a mediator in predicting negative post-purchase intentions. Research has emphasized the importance of service recovery as a chance to alter customers' negative attitude by resolving the problem (McDougall \& Levesque, 1999; Spreng et al., 1995; Swanson \& Hsu, 2009). This notion is similar to comments that a successful service recovery actually leads to more customer satisfaction and hence loyalty, positive word-of-mouth, and ultimately increased profits (Bitner et al., 1990; Hart et al., 1990; Spreng et al., 1995). 
In terms of the practical implications for hotel management, customer dissatisfaction directly influences forming customers' attitude. It suggests that hotel staff need to avoid the formation of a negative attitude among customers after they have become dissatisfied. However, if management discovers customer dissatisfaction, there is still a chance to restore the position by providing immediate solutions before the customer can take any negative action. For example, hotel management should offer a prompt apology and acknowledgement of service failure, show a dissatisfied customer responsiveness to the problems, and take whatever other service recovery actions are appropriate. This finding reinforces the message of previous work stressing the importance of immediate attention to service failure and the need to make a substantial and quick effort in service recovery to improve customers' negative assessment (Bradley \& Sparks, 2009; Ha \& Jang, 2009; Mattila \& Ro, 2008).

Thirdly, this study has shown that patrons of upscale hotels and those of budget hotels exhibit significant paths in the model of customer dissatisfaction and its consequences. It is known that, in general, customers of upscale hotels have high levels of expectation and those of budget hotels have low levels of expectation - and that these different classes of customer have different perceptions of value for money because they are aware that the different classes of hotel aim to provide different levels of hotel service, products, and facilities (Griffin et al., 1997; Hua et al., 2009; Kim et al., 2013; Knutson, 1988; Knutson et al., 1993). According to the cognitive theory, cognitive process in customer satisfaction/dissatisfaction, customer satisfaction and dissatisfaction are determined by customers' perceptions of the services actually provided: when the services meet or exceed their expectations, the customers are satisfied; when the services do not meet their expectations, they are dissatisfied (Oliver, 1980). 
However, customers who generally stay at upscale hotels and those who generally stay at budget hotels have different socio-cultural characteristics, such as income level, expenditure pattern, or travel frequency, so they may perceive each hotel class to be value-related criterion. We suggest that managers of upscale hotels need to identify the expectations of their targeted customers, while managers of budget hotels also need to understand budget hotel users in varying ways. The vital point is to understand that customer dissatisfaction generates negative attitudes and negative behavioral intentions in whatever the hotel class is. This implies that hotel class is not related to significant differences in the cognitive processes of customers who experience service failure. It should be recognized that, whatever the class of hotel, experiences that a hotel's customers find unsatisfactory should be prevented or remedied in a timely manner, before these customers form an enduring negative attitude toward the hotel.

Service failure is sometimes inevitable whatever the hotel star rating. The results of this study also show that dissatisfaction and its consequences in hotels of different classes were not distinctive. In fact, upscale hotel management tends to practice service recovery more proactively than their budget hotel counterparts (Sparks \& Bradley, 2014). However, this study demonstrates that management in both types of hotel should emphasize the importance of monitoring service failures and implementing active service recovery strategies when they occur. Even though budget hotels do not always allocate enough budgets for service recovery, they should not neglect this aspect and need to make a financial plan to sustainably maintain their business.

This study has some limitations, which give rise to suggestions for future research. Firstly, some studies have defined two distinctive types of attitude (antecedent and consequent) in constructing a model of customer satisfaction (Ekinci et al., 2008; Oliver, 1980). This study 
has investigated how consequent attitude, affected by dissatisfaction, leads directly to actual behavioral intention. Future work should also investigate the role of antecedent attitude where there is customer dissatisfaction. Secondly, this study explored whether or not there is a difference in the consequences of customer dissatisfaction between upscale and budget hotels. Therefore, a future study is also required which can test this model using respondents' sociodemographic and travel-related characteristics in order to understand whether the consequences of dissatisfaction and the role of attitude toward a hotel are consistent with these findings. Thirdly, although this research theoretically attempted to identify the effect of attitude toward a hotel on future intention, other components are excluded due to the focus on attitude toward a hotel. Therefore, a future study needs to expand the conceptual model to investigate the consequences of customer dissatisfaction. Fourthly, given the importance of service recovery as identified in this work, future research should investigate the impact of diverse service recovery strategies in improving an unfavorable attitude toward a hotel after an episode of dissatisfaction and hence mitigating unsatisfactory behavioral responses. 


\section{References}

Ajzen, I. (1985). From intentions to actions: A theory of planned behavior. In: Action control from cognition to behavior. Eds: Khul, J. and Beckmann, J. Berlin: Verlag. 10-39.

Ajzen, I. (1991). The theory of planned behavior. Organizational behavior and human decision processes, 50(2), 179-211.

Alegre, J., \& Garau, J. (2010). Tourist Satisfaction and Dissatisfaction. Annals of Tourism Research, 37(1), 52-73.

Allport, G. (1935). Attitudes. In C. Murchison (Ed.), Handbook for social psychology (798-884). Worchester, MA: Clark University Press.

Anderson, E.W. (1998). Customer Satisfaction and Word of Mouth. Journal of Service Research. I(1), 5-17.

Anderson, E.W., Fornell, C., \& Lehmann, D.R. (1994). Customer satisfaction, market share, and profitability: Findings from Sweden. The Journal of Marketing, 53-66.

Anderson, E.W., Fornell, C., \& Mazvancheryl, S.K. (2004). Customer satisfaction and shareholder value. Journal of marketing. 68(4), 172-185.

Anderson, E.W., \& Sullivan, M.W. (1993). The antecedents and consequences of customer satisfaction for firms. Marketing science, 12(2), 125-143.

Ariffin, A. A. M., \& Maghzi, A. (2012). A preliminary study on customer expectations of hotel hospitality: Influences of personal and hotel factors. International Journal of Hospitality Management, 31(1), 191-198.

Babin, B. J., \& Griffin, M. (1998). The nature of satisfaction: An updated examination and analysis. Journal of Business Research, 41(2), 127-136.

Baron, R. M., \& Kenny, D. A. (1986). The moderator-mediator variable distinction in social psychological research: Conceptual, strategic, and statistical considerations. Journal of Personality and Social Psychology, 51(6), 1173.

Bitner, M. J., Booms, B. H., \& Tetreault, M. S. (1990). The service encounter: diagnosing favorable and unfavorable incidents. Journal of Marketing, 54(1), 71-84.

Bolfing, C. P. (1989). How do customers express dissatisfaction and what can service marketers do about it?. Journal of Services Marketing, 3(2), 5-23.

Bollen, K.A. (1989). Structural Equations with Latent Variables, Wiley \& Sons, New York, NY.

Bougie, R., Pieters, R., \& Zeelenberg, M. (2003). Angry customers don't come back, they get back: The experience and behavioral implications of anger and dissatisfaction in services. Journal of the Academy of Marketing Science, 31(4), 377-393.

Bowen, J. T., \& Chen, S. L. (2001). The relationship between customer loyalty and customer satisfaction. International journal of contemporary hospitality management, 13(5), 213217.

Bradley, G. L., \& Sparks, B. A. (2009). Dealing with service failures: The use of explanations. Journal of Travel \& Tourism Marketing, 26(2), 129-143.

Cacioppo, J. T., \& Petty, R. E. (1981). Argument-Based Persuasion. Journal of personality and Social Psychology, 41(5), 847-855. 
Cardozo, R. N. (1965). An experimental study of customer effort, expectation, and satisfaction. Journal of marketing research 2(3), 244-249.

Chan, H., \& Wan, L. C. (2009). Dual Influences of Moderating Variables in the Dissatisfaction Process: Theory and Evidence. Journal of International Consumer Marketing, 21(2), 125-135.

Chan, H., Wan, L. C., \& Sin, L. Y. M. (2007). Hospitality service failures: Who will be more dissatisfied? International Journal of Hospitality Management, 26(3), 531-545.

Cheng, S., \& Lam, T. (2008). The role of the customer-seller relationship in the intention of the customer to complain: A study of Chinese restaurateurs. International Journal of Hospitality Management, 27(4), 552-562.

Cheng, S., Lam, T., \& Hsu, C.H. (2006). Negative word-of-mouth communication intention: An application of the theory of planned behavior. Journal of Hospitality \& Tourism Research, 30(1), 95-116.

Cheng, S., Lam, T., \& Hsu C.H.C. (2005). Testing the sufficiency of the theory of planned behavior: a case of customer dissatisfaction responses in restaurants. International Journal of Hospitality Management, 24(4), 475-492.

Cohen, A.R. (1964). Attitude Change and Social Influence.

Costa, G., Glinia, E., Goudas, M., \& Antoniou, P. (2004). Recreational services in resort hotels: Customer satisfaction aspects. Journal of Sport \& Tourism, 9(2), 117-126.

Dolnicar, S. (2002). Business travellers' hotel expectations and disappointments: A different perspective to hotel attribute importance investigation. Asia Pacific Journal of Tourism Research, 7(1), 29-35.

Eagly, A. H., \& Chaiken, S. (1993). The psychology of attitudes. Harcourt Brace Jovanovich College Publishers.

Ekinci, Y., Dawes, P. L., \& Massey, G. R. (2008). An extended model of the antecedents and consequences of consumer satisfaction for hospitality services. European Journal of Marketing, 42(1/2), 35-68.

Fazio, R.H. (1995). Attitudes as object-evaluation associations: Determinants, consequences, and correlates of attitude accessibility.

Fazio, R.H., Powell, M.C., \& Williams, C.J. (1989). The role of attitude accessibility in the attitude-to-behavior process. Journal of consumer research, 16(3), 280-288.

Fishbein, M., \& Ajzen, I. (1975). Belief, attitude, intention and behavior: An introduction to theory and research.

Fornell, C., \& Larcker, D.F. (1981). Evaluating structural equation models with unobservable variables and measurement error. Journal of marketing research, 39-50.

Fornell, C., \& Wernerfelt, B. (1987). Defensive marketing strategy by customer complaint management: a theoretical analysis. Journal of Marketing research, 24(4), 337-346.

Garcia-Falcon, J. M., \& Medina-Muñoz, D. (1999). The relationship between hotel companies and travel agencies: an empirical assessment of the United States market. Service Industries Journal, 19(4), 102-122. 
Griffin, R. K., Shea, L., \& Weaver, P. (1997). How business travelers discriminate between midpriced and luxury hotels: an analysis using a longitudinal sample. Journal of Hospitality \& Leisure Marketing, 4(2), 63-75.

Ha, J. \& Jang, S. (2009). Perceived justice in service recovery and behavioral intentions: The role of relationship quality. International Journal of Hospitality Management, 28(3), 319327.

Hair, J.F., Anderson, R.E., Tatham, R.L. \& Black, W.C. (2009). Multivariate data analysis with readings (7th ed.). Upper Saddle River, NJ: Prentice Hall.

Han, H., Hsu, L.T.J., \& Sheu, C. (2010). Application of the theory of planned behavior to green hotel choice: Testing the effect of environmental friendly activities. Tourism Management, 31(3), 325-334.

Hart, C. W., Heskett, J. L., \& Sasser Jr, W. E. (1990). The profitable art of service recovery. Harvard business review, 68(4), 148.

Hayes, A. F. (2009). Beyond Baron and Kenny: Statistical mediation analysis in the new millennium. Communication Monographs, 76(4), 408-420.

Herzberg, F. (1966). Work and the Nature of Man. (Vol. 3, No. 3). Cleveland: World Publishing Company.

Herzberg, F., Mausner, B., \& Snyderman, B.B. (1993). The Motivation to Work. Transaction Publishers, New Brunswick, New Jersey. Originally published in 1959 by John Wiley \& Sons, Inc.

Hoffman, K.D. \& Chung, B.G. (1999). Hospitality recovery strategies: Customer preference versus firm use. Journal of Hospitality \& Tourism Research. 23(1), 71-84.

Homburg, C., Koschate, N., \& Hoyer, W.D. (2005). Do satisfied customers really pay more? A study of the relationship between customer satisfaction and willingness to pay. Journal of Marketing. 69(2), 84-96.

Howard, J. A. (1974). The structure of buyer behavior. Consumer behavior: Theory and application, 9-32.

Hua, W., Chan, A., \& Mao, Z. (2009). Critical success factors and customer expectation in budget hotel segment - A case study of China. Journal of Quality Assurance in Hospitality \& Tourism, 10(1), 59-74.

Ingram, P., \& Roberts, P. W. (2000). Friendships among Competitors in the Sydney Hotel Industry1. American journal of sociology, 106(2), 387-423.

Jang, Y.J., Cho, S.B., \& Kim, W.G. (2013). Effect of Restaurant Patrons' Regret and Disappointment on Dissatisfaction and Behavioral Intention. Journal of Travel \& Tourism Marketing, 30(5), 431-444.

Jeong, M. \& Jeon, M.M. (2008). Customer reviews of hotel experiences through consumer generated media (CGM). Journal of Hospitality \& Leisure Marketing, 17(1-2), 121-138.

Jiang, J., Gretzel, U., \& Law, R. (2010). Do Negative Experiences Always Lead to Dissatisfaction?-Testing Attribution Theory in the Context of Online Travel Reviews. In Information and Communication Technologies in Tourism 2010 (pp. 297-308). 
Proceedings from the International Conference In Lugano Swizerland, 2010. Springer Vienna.

Johns, N., \& Howard, A. (1998). Customer expectations versus perceptions of service performance in the foodservice industry. International Journal of Service Industry Management, 9(3), 248-265.

Jones, D.L., McCleary, K.W., \& Lepisto, L.R. (2002). Consumer complaint behavior manifestations for table service restaurants: Identifying sociodemographic characteristics, personality, and behavioral factors. Journal of Hospitality \& Tourism Research. 26(2), 105-123.

Jöreskog, K. G., \& Sörbom, D. (1993). Lisrel 8: Structured equation modeling with the Simplis command language. Scientific Software International.

Kim, C., Kim, S., Im, S., \& Shin, C. (2003). The effect of attitude and perception on consumer complaint intentions. Journal of consumer marketing, 20(4), 352-371.

Kim, H.J. (2011). Service orientation, service quality, customer satisfaction, and customer loyalty: Testing a structural model. Journal of Hospitality Marketing \& Management. 20(6), 619-637.

Kim, J. H., \& Chen, J. S. (2010). The effects of situational and personal characteristics on consumer complaint behavior in restaurant services. Journal of Travel \& Tourism Marketing, 27(1), 96-112.

Kim, W. G., Cho, M., \& Brymer, R. A. (2013). Determinants affecting comprehensive propertylevel hotel performance: The moderating role of hotel type. International Journal of Hospitality Management, 34, 404-412.

Kline, R. B. (2011). Principles and practice of structural equation modeling. New York: Guilford.

Knutson, B. J. (1988). Frequent travelers: Making them happy and bringing them back. The Cornell Hotel and Restaurant Administration Quarterly, 29(1), 82-87.

Knutson, B., Stevens, P., Patton, M., \& Thompson, C. (1993). Consumers' expectations for service quality in economy, mid-price and luxury hotels. Journal of Hospitality \& Leisure Marketing, 1(2), 27-43.

Kokkinaki, F., \& Lunt, P. (1999). The effect of advertising message involvement on brand attitude accessibility. Journal of Economic Psychology, 20(1), 41-51.

Lee, J., Park, D. H., \& Han, I. (2008). The effect of negative online consumer reviews on product attitude: An information processing view. Electronic Commerce Research and Applications, 7(3), 341-352.

Lewis, R.C. (1983). When guests complain. Cornell Hotel and Restaurant Administration Quarterly. 24(2), 23-32.

Lutz, R.J. (1991). The Role of Attitude Theory in Marketing, in Harold H. Kassarjian and J. J. Robertson, eds., Perspectives in Consumer Behavior, Prentice-Hall, 4th ed., 317-339.

Maddox, R. N. (1981). Two-factor theory and Consumer Satisfaction: Replication and Extension. Journal of Consumer Research, 8(1), 97-102.

Maio, G., \& Haddock, G. (2009). The psychology of attitudes and attitude change. SAGE 
Publications Limited.

Maio, G. R., \& Olson, J. M. (1995). Relations between values, attitudes, and behavioral intentions: The moderating role of attitude function. Journal of Experimental Social Psychology, 31(3), 266-285.

MacCallum, R. C., Browne, M. W., \& Sugawara, H. M. (1996). Power analysis and determination of sample size for covariance structure modeling. Psychological Methods, $1(2), 130$.

MacKinnon, D. P., Warsi, G., \& Dwyer, J. H. (1995). A simulation study of mediated effect measures. Multivariate behavioral research, 30(1), 41-62.

Mattila, A. S., \& Ro, H. (2008). Discrete Negative Emotions and Customer Dissatisfaction Responses in a Casual Restaurant Setting. Journal of Hospitality \& Tourism Research, 32(1), 89-107.

McDougall, G. H., \& Levesque, T. J. (1999). Waiting for service: the effectiveness of recovery strategies. International Journal of Contemporary Hospitality Management, 11(1), 6-15.

Musante, M. D., Bojanic, D. C., \& Zhang, J. (2009). An evaluation of hotel website attribute utilization and effectiveness by hotel class. Journal of Vacation Marketing, 15(3), 203215.

Myers, M. B., Calantone, R. J., Page Jr, T. J., \& Taylor, C. R. (2000). An application of multiplegroup causal models in assessing cross-cultural measurement equivalence. Journal of International Marketing, 8(4), 108-121.

Oliver, R.L. (1980). A cognitive model of the antecedents and consequences of satisfaction decisions. Journal of marketing research, 17(4), 460-469.

Olsen, S.O. (2002). Comparative evaluation and the relationship between quality, satisfaction, and repurchase loyalty. Journal of the Academy of Marketing Science, 30(3), 240-249.

Olson, J.C., \& Dover, P.A. (1979). Disconfirmation of consumer expectations through product trial. Journal of Applied Psychology, 64(2), 179.

Olson, J.C., \& Mitchell, A.A. (1975). The process of attitude acquisition: The value of a developmental approach to consumer attitude research. Advances in consumer research, 2(1), 249-265.

Preacher, K., \& Hayes, A. (2004). SPSS and SAS procedures for estimating indirect effects in simple mediation models. Behavior Research Methods. Instruments, \& Computers, 36, 717-731.

Priester, J. R., Nayakankuppam, D., Fleming, M. A., \& Godek, J. (2004). The A2SC2 model: The influence of attitudes and attitude strength on consideration and choice. Journal of Consumer Research, 30(4), 574-587.

Reichheld, F. (1996). The Loyalty Effect, Harvard Business School Press, Cambridge, MA.

Reichheld, F. F., \& Sasser Jr, W. E. (1990). Zero defections: quality comes to services. Harvard business review, 68(5), 105.

Richins, L.M. (1987). A multivariate analysis of responses to dissatisfaction. Journal of the Academy of Marketing Science. 15(3), 24-31.

Richins, M. L. (1983). Negative word-of-mouth by dissatisfied consumers: A pilot study. Journal of Marketing, 47(1), 68-78. 
Ro, H. (2012). Moderator and mediator effects in hospitality research. International Journal of Hospitality Management, 31(3), 952-961.

Ro, H., \& Wong, J. (2012). Customer opportunistic complaints management: A critical incident Approach. International Journal of Hospitality Management. 31(2), 419-427.

Rokeach, M., \& Kliejunas, P. (1972). Behavior as a function of attitude-toward-object and attitude-toward-situation.

Sánchez-García, I., \& Currás-Pérez, R. (2011). Effects of Dissatisfaction in Tourist Services: The role of anger and regret. Tourism Management, 32(6), 1397-1406.

Sanes, C. (1993). Mining the gold in customer complaints-Complaints are hidden treasure. Journal for Quality and Participation. 16(5).

Schlossberg, H. (1991). Customer Satisfaction: Not a Fad, but a Way of Life. Marketing News. 25(20), 18-21.

Sparks, B.A. \& Bradley, G. L. (2014). A “Triple A” Typology of Responding to Negative Consumer-Generated Online Reviews, Journal of Hospitality \& Tourism Research, 1096348014538052.

Spreng, R. A., Harrell, G. D., \& Mackoy, R. D. (1995). Service recovery: impact on satisfaction and intentions. Journal of Services Marketing, 9(1), 15-23.

Swan, J. E., \& Combs, L. J. (1976). Product performance and consumer satisfaction: a new concept. The Journal of Marketing, 40(2), 25-33.

Swanson, S. R., \& Hsu, M. K. (2009). Critical incidents in tourism: Failure, recovery, customer switching, and word-of-mouth behaviors. Journal of Travel \& Tourism Marketing, 26(2), 180-194.

Technical Assistance Research Program (TARP). (1981). Measuring the Grapevine: Consumer Response and Word-of-Mouth, Atlanta, GA: Coca-Cola.

Velázquez, B. M., Blasco, M. F., Contrí, G. B., \& Saura, I. G. (2009). Cognitive and affective causes of consumer dissatisfaction with the hospitality encounter. Journal of Hospitality Marketing \& Management, 18(7), 653-675.

Vermeulen, I. E., \& Seegers, D. (2009). Tried and tested: The impact of online hotel reviews on consumer consideration. Tourism Management, 30(1), 123-127.

Wicker, A. W. (1969). Attitudes versus actions: The relationship of verbal and overt behavioral responses to attitude objects. Journal of social issues, 25(4), 41-78.

Yang, W. \& Mattila, A. S. (2012). The role of tie strength on consumer dissatisfaction responses. International Journal of Hospitality Management, 31(2), 399-404.

Yi, Y. (1990). A critical review of consumer satisfaction. Review of marketing, 4, 68-123.

Yoo, B. (2002). Cross-group comparisons: A cautionary note. Psychology \& Marketing, 19(4), 357-368.

Yuksel, A., Kilinc, U., \& Yuksel, F. (2006). Cross-national analysis of hotel customers' attitudes toward complaining and their complaining behaviours. Tourism Management, 27(1), 1124.

Zainol, N. A., Lockwood, A., \& Kutsch, E. (2010). Relating the zone of tolerance to service failure in the hospitality industry. Journal of Travel \& Tourism Marketing, 27(3), 324- 
333.

Zanna, M. P., \& Rempel, J. K. (1988). Attitudes: A new look at an old concept.

Zeelenberg, M. \& Pieters, R. (2004). Beyond valence in customer dissatisfaction: A review and new findings on behavioral responses to regret and disappointment in failed services. Journal of Business Research. 57(4), 445-455.

Zeithaml, V.A., Berry, L.L., \& Parasuraman, A. (1996). The Behavioral Consequences of Service Quality. Journal of Marketing. 60(2), 31-46. 
Table 1 Validity and reliability for constructs

\begin{tabular}{|c|c|c|c|c|c|c|c|c|c|c|c|}
\hline \multirow[b]{2}{*}{ Construct } & \multirow[b]{2}{*}{ Item } & \multicolumn{5}{|c|}{ Upscale hotel dataset $(N=325)$} & \multicolumn{5}{|c|}{ Budget hotel dataset $(N=322)$} \\
\hline & & $\begin{array}{c}\text { Factor } \\
\text { loading }\end{array}$ & $t$-value & SMC & AVE & CCR & $\begin{array}{l}\text { Factor } \\
\text { loading }\end{array}$ & $t$-value & $\mathrm{SMC}$ & AVE & $\mathrm{CCR}$ \\
\hline \multirow{3}{*}{$\mathrm{CD}$} & As a whole, I was __ with the "Hotel A/B". & .99 & $-^{a}$ & .98 & \multirow{3}{*}{0.87} & \multirow{3}{*}{0.95} & .99 & $--^{a}$ & .98 & \multirow{3}{*}{0.91} & \multirow{3}{*}{0.97} \\
\hline & $\begin{array}{l}\text { I was } \\
\text { A/B" a a a }\end{array}$ & .98 & 65.53 & .95 & & & .99 & 90.58 & .98 & & \\
\hline & I was with the overall quality of the "Hotel A/B". & .99 & 83.36 & .98 & & & .98 & 76.60 & .97 & & \\
\hline \multirow{7}{*}{ AT } & Favorable - Unfavorable & .96 & $-^{a}$ & .93 & \multirow{7}{*}{0.82} & \multirow{7}{*}{0.97} & .94 & $-^{a}$ & .89 & \multirow{7}{*}{0.79} & \multirow{7}{*}{0.96} \\
\hline & Positive - Negative & .98 & 52.58 & .97 & & & .95 & 36.26 & .90 & & \\
\hline & Good - Bad & .98 & 50.59 & .96 & & & .95 & 35.78 & .90 & & \\
\hline & Like - Dislike & .98 & 50.33 & .96 & & & .94 & 34.23 & .88 & & \\
\hline & Rewarding - Punishing & .93 & 37.11 & .87 & & & .78 & 20.29 & .61 & & \\
\hline & Attractive - Unattractive & .96 & 42.69 & .91 & & & .87 & 26.50 & .76 & & \\
\hline & Valuable - Worthless & .91 & 33.87 & .83 & & & .84 & 24.17 & .71 & & \\
\hline \multirow{4}{*}{ SW } & I will NOT stay at the "Hotel A/B" after the experience. & .93 & $-^{a}$ & .86 & \multirow{4}{*}{0.77} & \multirow{4}{*}{0.93} & .92 & $-^{a}$ & .84 & \multirow{4}{*}{0.79} & \multirow{4}{*}{0.94} \\
\hline & I will NOT use the services of the "Hotel A/B" in the future. & .92 & 29.04 & .85 & & & .97 & 34.13 & .94 & & \\
\hline & I will NOT return to the "Hotel A/B" in the future. & .91 & 27.50 & .82 & & & .95 & 32.26 & .91 & & \\
\hline & I will switch to another competing hotel for my needs. & .83 & 22.24 & .70 & & & .73 & 16.81 & .53 & & \\
\hline \multirow{4}{*}{ NW } & $\begin{array}{l}\text { I will say negative things about the "Hotel } \mathrm{A} / \mathrm{B} \text { " to other } \\
\text { people. }\end{array}$ & .86 & ${ }_{-}^{a}$ & .73 & \multirow{4}{*}{0.70} & \multirow{4}{*}{0.90} & .76 & ${ }_{-}^{a}$ & .57 & \multirow{4}{*}{0.62} & \multirow{4}{*}{0.87} \\
\hline & $\begin{array}{l}\text { I will discourage friends and family from going to the "Hotel } \\
\text { A/B". }\end{array}$ & .93 & 23.81 & .87 & & & .90 & 16.87 & .81 & & \\
\hline & $\begin{array}{l}\text { I will advise against the "Hotel A/B" when someone seeks } \\
\text { my advice. }\end{array}$ & .90 & 22.19 & .81 & & & .85 & 15.78 & .72 & & \\
\hline & $\begin{array}{l}\text { I will speak to my friends and relatives about my bad } \\
\text { experience. }\end{array}$ & .86 & 20.66 & .75 & & & .78 & 14.40 & .61 & & \\
\hline \multirow{5}{*}{$\mathrm{CP}$} & I will let staff know about the problem. & .93 & $-^{a}$ & .87 & \multirow{4}{*}{0.53} & \multirow{4}{*}{0.81} & .85 & $-^{a}$ & .73 & \multirow{4}{*}{0.49} & \multirow{4}{*}{0.79} \\
\hline & $\begin{array}{l}\text { I will complain to the "Hotel A/B" about the poor quality of } \\
\text { service. }\end{array}$ & .95 & 30.54 & .89 & & & .94 & 21.65 & .88 & & \\
\hline & I will directly ask staff to solve the problem. & .73 & 17.26 & .54 & & & .75 & 15.76 & .56 & & \\
\hline & I will file a written complaint. & .64 & 13.76 & .41 & & & .68 & 13.71 & .46 & & \\
\hline & Fit indices & \multicolumn{5}{|c|}{$\begin{array}{l}\left.\chi^{2}=596.31, d f=199, \chi^{2} / d f=2.86, p<.000\right), \\
\text { TLI=.96, CFI }=.96, \text { RMSEA }=.08, \text { NFI }=.95\end{array}$} & $\chi^{2}=592.0$ & $\begin{array}{ll}f=199, \chi \\
I=.96, \mathrm{RN}\end{array}$ & $\begin{array}{l}l f=2.98, \\
E A=.08\end{array}$ & $\begin{array}{l}<.000, \mathrm{~T} \\
\mathrm{JFI}=.93 \\
\end{array}$ & $\mathrm{I}=.95$, \\
\hline $\begin{array}{l}\text { 2. Hotel A ind } \\
\text { 3. Items for } \mathrm{C} \\
\text { 4. } t \text {-value on a } \\
\text { 5. }-^{a} \text { In the } \mathrm{m} \\
\text { 6. Average Va }\end{array}$ & $\begin{array}{l}\text { stomer dissatisfaction), AT (attitude toward a hotel), SW (switc } \\
\text { ates upscale hotel, whereas Hotel B indicates budget hotel. } \\
\text { were measured on a seven-Likert scale with } 1 \text { indicating "not to } \\
\text { items were significant at the } .001 \text { level. } \\
\text { surement model, the estimated parameter was fixed at } 1.0 \text {. } \\
\text { ance Extracted (AVE) }=\left(\sum \text { standardized loadings }{ }^{2}\right) /\left[\left(\sum \text { stan }\right.\right. \\
\left.\text { onstruct Reliability }(\mathrm{CCR})=\sum \text { standardized loadings) }\right)^{2} /\left[\left(\sum \text { st }\right.\right.\end{array}$ & lly dissatis & $\begin{array}{l}\text { vider), } N \\
\text { d" } 4 \text { indic }\end{array}$ & ing " $\mathrm{N}$ & al", to & Idica & "highly & $\begin{array}{l}\text { aining). } \\
\text { tisfied". }\end{array}$ & & & \\
\hline
\end{tabular}


Table 2 Correlations matrix of upscale and budget hotel datasets

\begin{tabular}{|c|c|c|c|c|c|c|c|c|c|c|c|c|c|c|}
\hline \multirow{2}{*}{$\begin{array}{c}\text { Construc } \\
\mathrm{t}\end{array}$} & \multicolumn{7}{|c|}{ Upscale hotel dataset $(N=325)$} & \multicolumn{7}{|c|}{ Budget hotel dataset $(N=322)$} \\
\hline & Mean & S.D & CD & AT & SW & NW & $\mathrm{CP}$ & Mean & S.D & $\mathrm{CD}$ & AT & SW & NW & $\mathrm{CP}$ \\
\hline $\mathrm{CD}$ & 5.67 & 2.15 & 1.00 & & & & & 5.77 & 2.04 & 1.00 & & & & \\
\hline AT & 6.12 & 1.52 & $.39 * *$ & 1.00 & & & & 6.28 & 0.95 & $.28 * *$ & 1.00 & & & \\
\hline SW & 6.31 & 1.03 & $.23^{* *}$ & $.55 * *$ & 1.00 & & & 6.43 & 0.93 & $.26 * *$ & $.72 * *$ & 1.00 & & \\
\hline NW & 6.04 & 1.15 & $.23^{* *}$ & $.49 * *$ & $.77 * *$ & 1.00 & & 6.14 & 0.97 & $.25 * *$ & $.60 * *$ & $.69 * *$ & 1.00 & \\
\hline $\mathrm{CP}$ & 6.06 & 1.13 & $.19^{* *}$ & $.42 * *$ & $.62 * *$ & $.70 * *$ & 1.00 & 5.91 & 1.12 & $.19^{* *}$ & $.51 * *$ & $.52 * *$ & $.52 * *$ & 1.00 \\
\hline
\end{tabular}

Note: 1. CD (customer dissatisfaction), AT (attitude toward a hotel), SW (switching service provider), NW

(spreading negative word-of-mouth), CP (complaining)

2. $* * p<.01$ 
Table 3 Standardized direct, indirect, and total effects of the hypothesized models

\begin{tabular}{|c|c|c|c|c|c|c|c|c|c|}
\hline \multicolumn{10}{|c|}{ Upscale hotel dataset $(N=325)$} \\
\hline & \multirow[b]{3}{*}{ Path } & \multirow[b]{3}{*}{$\begin{array}{c}\text { Point } \\
\text { estimat } \\
\text { e }\end{array}$} & \multirow[b]{3}{*}{ SE } & \multicolumn{6}{|c|}{ Bootstrapping } \\
\hline & & & & \multicolumn{3}{|c|}{ Percentile $90 \% \mathrm{CI}$} & \multicolumn{3}{|c|}{ Bias-corrected percentile } \\
\hline & & & & $\begin{array}{l}\text { Lowe } \\
\mathrm{r}\end{array}$ & $\begin{array}{l}\text { Uppe } \\
\text { r }\end{array}$ & $\begin{array}{c}\text { Two-tailed } \\
\text { significanc } \\
\text { e }\end{array}$ & $\begin{array}{l}\text { Lowe } \\
\mathrm{r}\end{array}$ & Upper & $\begin{array}{l}\text { Two-tailed } \\
\text { significance }\end{array}$ \\
\hline \multirow{7}{*}{$\begin{array}{c}\text { Standardize } \\
\text { d direct } \\
\text { effects }\end{array}$} & $\mathrm{CD} \rightarrow \mathrm{SW}$ & .01 & .03 & -.08 & .09 & .93 & -.08 & .10 & .89 \\
\hline & $\mathrm{CD} \rightarrow \mathrm{NW}$ & .03 & .03 & -.06 & .12 & .60 & -.06 & .12 & .55 \\
\hline & $\mathrm{CD} \rightarrow \mathrm{CP}$ & .01 & .03 & -.08 & .10 & .82 & -.08 & .10 & .82 \\
\hline & $\mathrm{CD} \rightarrow \mathrm{AT}$ & .41 & .04 & .32 & .48 & $.00^{* *}$ & .32 & .48 & $.00^{* *}$ \\
\hline & $\mathrm{AT} \rightarrow \mathrm{SW}$ & .56 & .04 & .49 & .64 & $.00^{* *}$ & .48 & .63 & $.00^{* *}$ \\
\hline & $\mathrm{AT} \rightarrow \mathrm{NW}$ & .50 & .04 & .42 & .58 & $.00^{* *}$ & .41 & .58 & $.00^{* *}$ \\
\hline & $\mathrm{AT} \rightarrow \mathrm{CP}$ & .50 & .04 & .42 & .58 & $.00^{* *}$ & .41 & .57 & $.00^{* *}$ \\
\hline \multirow{3}{*}{$\begin{array}{l}\text { Standardize } \\
\mathrm{d} \text { indirect } \\
\text { effects }\end{array}$} & $\mathrm{CD} \rightarrow \mathrm{AT} \rightarrow \mathrm{SW}$ & .23 & .03 & .17 & .28 & $.00^{* *}$ & .17 & .29 & $.00^{* *}$ \\
\hline & $\begin{array}{l}\mathrm{CD} \rightarrow \mathrm{AT} \rightarrow \mathrm{N} \\
\mathrm{W}\end{array}$ & .20 & .03 & .15 & .26 & $.00^{* *}$ & .15 & .26 & $.00^{* *}$ \\
\hline & $\mathrm{CD} \rightarrow \mathrm{AT} \rightarrow \mathrm{CP}$ & .20 & .03 & .15 & .26 & $.00^{* *}$ & .15 & .26 & $.00^{* *}$ \\
\hline \multirow{7}{*}{$\begin{array}{l}\text { Standardize } \\
\text { d total } \\
\text { effects }\end{array}$} & $\mathrm{CD} \rightarrow \mathrm{SW}$ & .23 & .05 & .14 & .32 & $.00 * *$ & .14 & .32 & $.00 * *$ \\
\hline & $\mathrm{CD} \rightarrow \mathrm{NW}$ & .23 & .05 & .14 & .32 & $.00 * *$ & .14 & .32 & $.00 * *$ \\
\hline & $\mathrm{CD} \rightarrow \mathrm{CP}$ & .21 & .05 & .12 & .31 & $.00 * *$ & .12 & .30 & $.00 * *$ \\
\hline & $\mathrm{CD} \rightarrow \mathrm{AT}$ & .41 & .05 & .32 & .48 & $.00 * *$ & .32 & .48 & $.00 * *$ \\
\hline & $\mathrm{AT} \rightarrow \mathrm{SW}$ & .56 & .05 & .48 & .64 & $.00 * *$ & .48 & .63 & $.00 * *$ \\
\hline & $\mathrm{AT} \rightarrow \mathrm{NW}$ & .50 & .05 & .42 & .58 & $.00^{* *}$ & .41 & .58 & $.00^{* *}$ \\
\hline & $\mathrm{AT} \rightarrow \mathrm{CP}$ & .50 & .05 & .42 & .58 & $.00^{* *}$ & .41 & .57 & $.00^{* *}$ \\
\hline \multicolumn{10}{|c|}{ Budget hotel dataset $(N=322)$} \\
\hline & & & & \multicolumn{6}{|c|}{ Bootstrapping } \\
\hline & & & & \multicolumn{3}{|c|}{ Percentile $90 \%$ CI } & \multicolumn{3}{|c|}{ Bias-corrected percentile } \\
\hline & Path & $\begin{array}{l}\text { Point } \\
\text { estimate }\end{array}$ & SE & $\begin{array}{l}\text { Lowe } \\
\mathrm{r}\end{array}$ & $\begin{array}{l}\text { Uppe } \\
\text { r }\end{array}$ & $\begin{array}{c}\text { Two-tailed } \\
\text { significanc } \\
\mathrm{e}\end{array}$ & $\begin{array}{l}\text { Lowe } \\
\mathrm{r}\end{array}$ & Upper & $\begin{array}{c}\text { Two- } \\
\text { tailed } \\
\text { significa } \\
\text { nce }\end{array}$ \\
\hline \multirow{7}{*}{$\begin{array}{l}\text { Standardize } \\
\text { d direct } \\
\text { effects }\end{array}$} & $\mathrm{CD} \rightarrow \mathrm{SW}$ & .06 & .05 & .00 & .12 & .09 & .01 & .13 & .07 \\
\hline & $\mathrm{CD} \rightarrow \mathrm{NW}$ & .09 & .06 & -.01 & .19 & .14 & -.00 & .19 & .11 \\
\hline & $\mathrm{CD} \rightarrow \mathrm{CP}$ & .07 & .04 & -.01 & .16 & .17 & -.01 & .16 & .15 \\
\hline & $\mathrm{CD} \rightarrow \mathrm{AT}$ & .28 & .05 & .19 & .37 & $.00^{* *}$ & .19 & .37 & $.00^{* *}$ \\
\hline & $\mathrm{AT} \rightarrow \mathrm{SW}$ & .71 & .04 & .63 & .78 & $.00 * *$ & .63 & .78 & $.00^{* *}$ \\
\hline & $\mathrm{AT} \rightarrow \mathrm{NW}$ & .63 & .06 & .54 & .72 & $.00^{* *}$ & .53 & .71 & $.00^{* *}$ \\
\hline & $\mathrm{AT} \rightarrow \mathrm{CP}$ & .55 & .07 & .44 & .65 & $.00 * *$ & .44 & .65 & $.00 * *$ \\
\hline \multirow{3}{*}{$\begin{array}{l}\text { Standardize } \\
\mathrm{d} \text { indirect } \\
\text { effects }\end{array}$} & $\mathrm{CD} \rightarrow \mathrm{AT} \rightarrow \mathrm{SW}$ & .12 & .04 & .13 & .27 & $.00 * *$ & .13 & .27 & $.00 * *$ \\
\hline & $\begin{array}{l}\mathrm{CD} \rightarrow \mathrm{AT} \rightarrow \mathrm{N} \\
\mathrm{W}\end{array}$ & .18 & .04 & .11 & .25 & $.00^{* *}$ & .12 & .25 & $.00 * *$ \\
\hline & $\mathrm{CD} \rightarrow \mathrm{AT} \rightarrow \mathrm{CP}$ & .15 & .04 & .10 & .22 & $.00^{* *}$ & .10 & .23 & $.00^{* *}$ \\
\hline \multirow{7}{*}{$\begin{array}{c}\text { Standardize } \\
\text { d total } \\
\text { effects }\end{array}$} & $\mathrm{CD} \rightarrow \mathrm{SW}$ & .26 & .05 & .17 & .35 & $.00 * *$ & .18 & .35 & $.00 * *$ \\
\hline & $\mathrm{CD} \rightarrow \mathrm{NW}$ & .27 & .06 & .16 & .36 & $.00 * *$ & .17 & .37 & $.00^{* *}$ \\
\hline & $\mathrm{CD} \rightarrow \mathrm{CP}$ & .23 & .06 & .13 & .32 & $.00 * *$ & .13 & .32 & $.00^{* *}$ \\
\hline & $\mathrm{CD} \rightarrow \mathrm{AT}$ & .28 & .05 & .19 & .37 & $.00 * *$ & .19 & .37 & $.00 * *$ \\
\hline & $\mathrm{AT} \rightarrow \mathrm{SW}$ & .71 & .04 & .63 & .78 & $.00 * *$ & .63 & .78 & $.00^{* *}$ \\
\hline & $\mathrm{AT} \rightarrow \mathrm{NW}$ & .63 & .06 & .54 & .72 & $.00^{* *}$ & .53 & .71 & $.00 * *$ \\
\hline & $\mathrm{AT} \rightarrow \mathrm{CP}$ & .55 & .07 & .44 & .65 & $.00^{* *}$ & .44 & .65 & $.00 * *$ \\
\hline
\end{tabular}

Note: $* * p<.01$. 
Table 4 Results of measurement invariance test for customer groups of upscale and budget hotels

\begin{tabular}{ccccccccccc}
\hline Model & $\chi^{2}$ & $\mathrm{df}$ & $\chi^{2} / d f$ & TLI & CFI & RMSEA & NFI & $\Delta \chi^{2}$ & Sig. & Support \\
\hline $\begin{array}{c}\text { Non- } \\
\text { constrained } \\
\text { model }\end{array}$ & 1188.36 & 398 & 2.99 & .95 & .96 & .06 & .94 & & & \\
\hline $\begin{array}{c}\text { Factor } \\
\text { loading } \\
\text { constrained } \\
\text { model }\end{array}$ & 1217.68 & 415 & 2.93 & .95 & .96 & .06 & .94 & $\begin{array}{c}29.32 \\
(17)\end{array}$ & $\begin{array}{c}p<.05 \\
\text { significant } \\
(27.59)\end{array}$ & $\begin{array}{c}\text { Not } \\
\text { supported }\end{array}$ \\
\hline $\begin{array}{c}\text { Covariance } \\
\text { constrained } \\
\text { model }\end{array}$ & 1307.37 & 413 & 3.17 & .95 & .95 & .06 & .94 & $\begin{array}{c}119.01 \\
(15)\end{array}$ & $\begin{array}{c}p<.05 \\
\text { significant } \\
(25.00)\end{array}$ & $\begin{array}{c}\text { Not } \\
\text { supported }\end{array}$ \\
\hline $\begin{array}{c}\text { Factor } \\
\text { oading and } \\
\text { covariance } \\
\text { constrained } \\
\text { model }\end{array}$ & 1368.10 & 430 & 3.18 & .95 & .95 & .06 & .93 & $\begin{array}{c}179.74 \\
(32)\end{array}$ & $\begin{array}{c}p<.05 \\
\text { significant } \\
(43.77)\end{array}$ & $\begin{array}{c}\text { Not } \\
\text { supported }\end{array}$ \\
\hline
\end{tabular}


Figure 1 Results of the structural model analyses

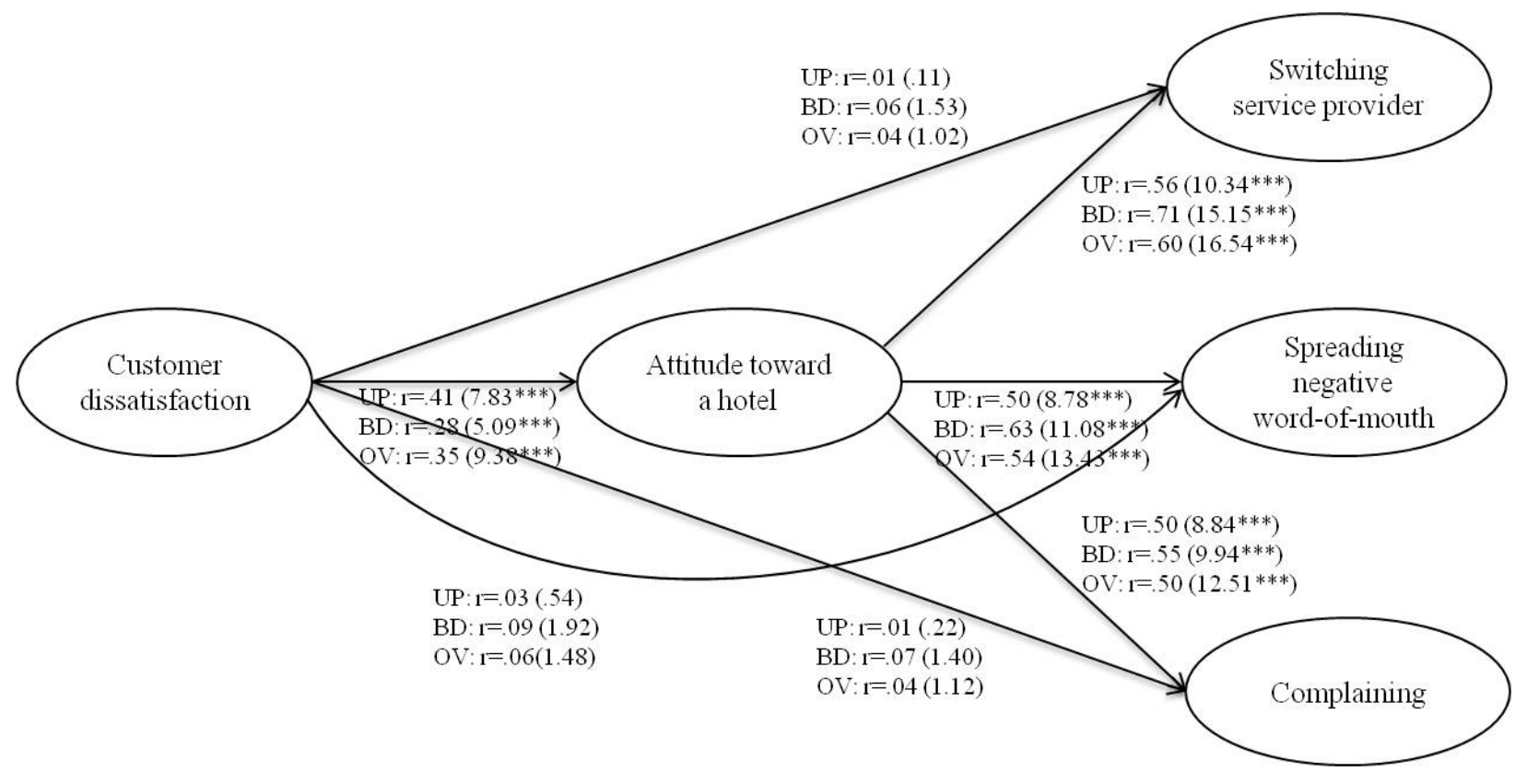

Note: $* * * * p<.001$

Upscale hotel dataset (UP) $(\mathrm{N}=325, \chi 2(202)=959.91, \chi 2 / d f=4.75, p<.001, \mathrm{TLI}=92, \mathrm{CFI}=93, \mathrm{RMSEA}=.11, \mathrm{NFI}=91$

Budget hotel dataset $(\mathrm{BD})(\mathrm{N}=322, \chi 2(202)=711.11, \chi 2 / d f=3.52, p<.001, \mathrm{TLI}=93, \mathrm{CFI}=94, \mathrm{RMSEA}=.09, \mathrm{NFI}=92$

Overall hotel dataset $(\mathrm{OV})\left(\mathrm{N}=647, \chi_{2}(202)=1286.278, \chi 2 / d f=6.368, p<.001, \mathrm{TLI}=.94, \mathrm{CFI}=.94, \mathrm{RMSEA}=.09, \mathrm{NFI}=.93\right.$ 
Figure 2 Direct effects of customer dissatisfaction on three negative behavioral intentions

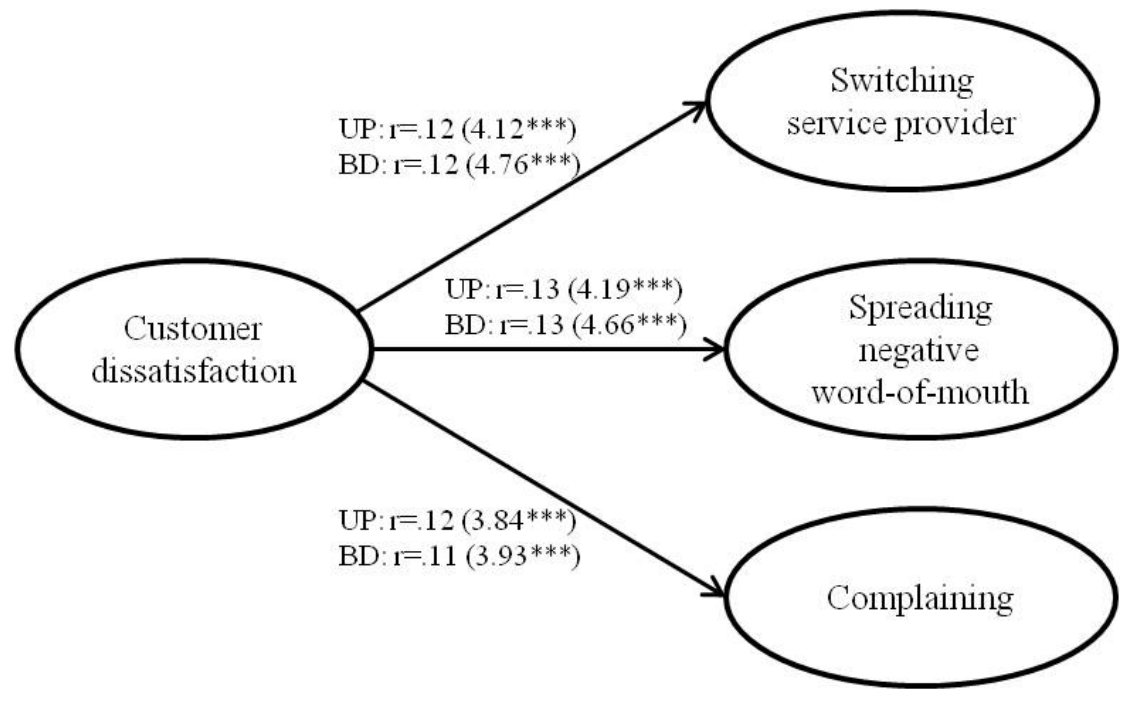

Note: ${ }^{* * *} p<.001$ 